\title{
O candomblé da Bahia na década de $1930^{*}$
}

\author{
VIVALDO DA COSTA LIMA
}

\section{Martiniano e Aninha foram as figuras mais importantes e prestigiosas do camdomblé na Bahia naquela época}

$\mathrm{D}$ OS MUITOS LÍDERES religiosos que exerciam, com maior ou menor influência comunitária, papéis importantes nos candomblés da Bahia, nos anos de 1930, dois se destacavam de maneira indiscutível: o babalaô Martiniano Eliseu do Bonfim e a ialorixá Eugênia Ana dos Santos, Aninha, do Centro Cruz Santa do Axé do Opô Afonjá.

Suas personalidades transcendiam o ambiente dos terreiros e se impunham, igualmente, à sociedade inclusiva. Édison Carneiro, em artigo na edição come-

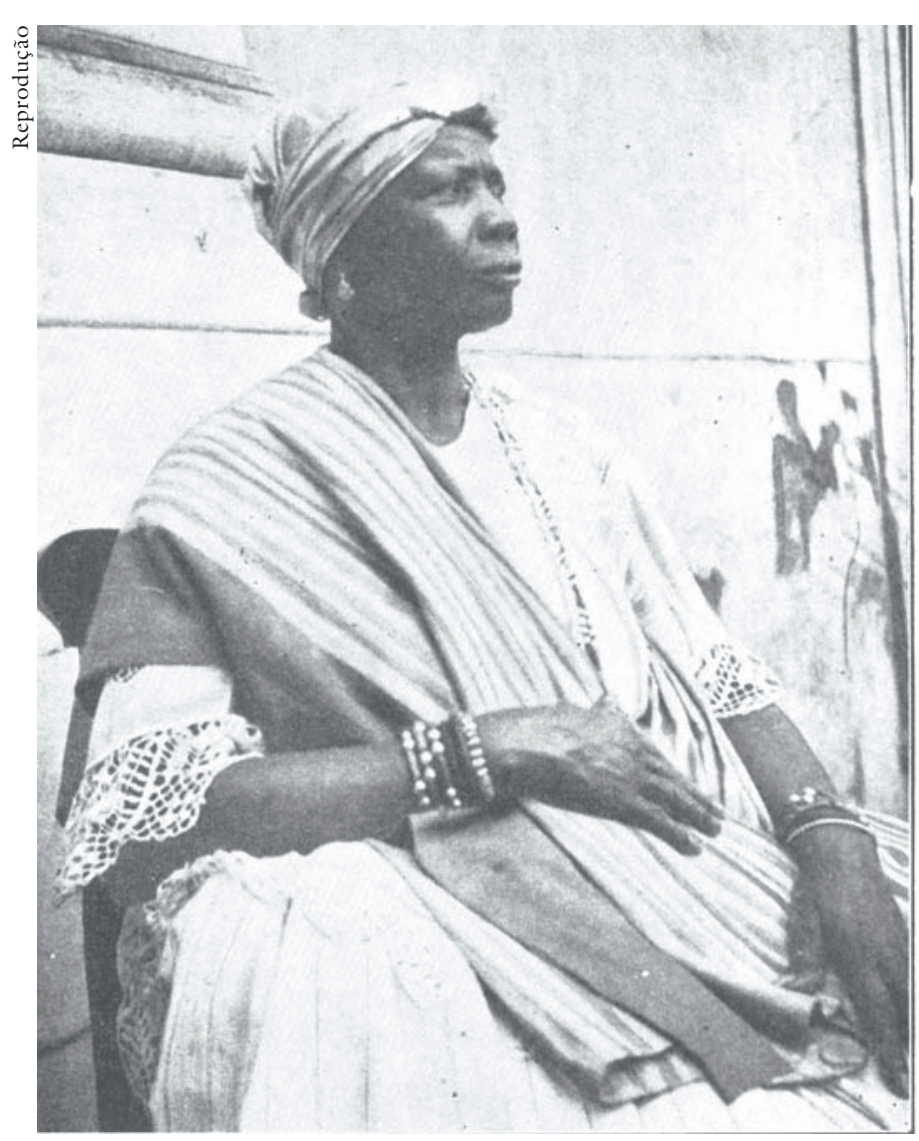

A ialorixá Eugênia Ana dos Santos, a famosa Aninha. morativa do 4 o Centenário da Cidade do Salvador do jornal $A$ Tarde, em 29 de março de 1949 - "Lembrança do negro na $\mathrm{Ba}-$ hia" (republicado, em 1964, no livro Ladinos e crioulos), falando da "extraordinária importância para a nacionalidade da contribuição do negro", diz: "Esta contribuição se estendeu, com intensidade variável, a todos os campos da atividade humana, entre os quais a luta política pela reforma da sociedade, produzindo figuras eminentes, com os pardos da Teodoro Sampaio, Martiniano do Bonfim e Aninha". Carneiro estava certo em incluir es- 
ses dois líderes religiosos, por sua intensa atuação na sociedade global, no plano da influência política, no sentido atual e abrangente do conceito de política. Carneiro foi amigo de ambos, de Martiniano e de Aninha. O babalaô é mencionado muitas vezes nas cartas dessa Correspondência e Aninha, citada, embora, uma vez apenas, o foi de um modo que resume sua personalidade forte e sensível. Na carta de 8 de janeiro de 1938, Nelson Carneiro informa a Artur Ramos: "Morreu há dias, D. Aninha, do Opô Afonjá, braço do Congresso, sua admiradora". Pode-se imaginar quanto terá custado a Édison Carneiro resumir, nesta curta frase, carregada de intenções, todos os sentidos de respeito e gratidão que mantinha pela falecida ialorixá, desde a ajuda que ela lhe prestou na realização do Congresso até o'santuário que lhe concedeu, no seu terreiro de São Gonçalo, no fim do ano de 1937, quando Carneiro ali se refugiou da perseguição da polícia política. Este fato, lembrado por Carneiro a Senhora e seus Obás, muitos anos depois, é também mencionado no livro de Deoscóredes M. Santos, filho de Senhora, Açobá do terreiro, no seu livro Axé Opô Afonjá:

Em fins de 1937, com a proclamação do Estado Novo, o escritor e etnógrafo Édison Carneiro, sendo perseguido, refugiou-se no terreiro, tendo Mãe Aninha encarregou Senhora de velar por ele, lhe prestar assistência. Esse fato por muitos anos foi conhecido apenas de Aninha e Senhora, até que o mesmo Édison Carneiro deu-lhe divulgação pública.

Nas suas cartas a Ramos, Carneiro tinha que ser discreto e não aludir a fatos e situações que pudessem vir a comprometer seus amigos dos candomblés.

"Nessas duas figuras singulares bem se poderiam identificar as clássicas categorias weberianas da legitimação do poder ..."

Martiniano e Aninha são atualmente nomes lembrados na tradição oral de todos os terreiros da Bahia, mitificados já, na lembrança da "gente-de-santo", dos que os conheceram em vida e dos que ouviram contar histórias de seu poder, de seu conhecimento, de seu imenso prestígio. Nessas duas figuras singulares bem se poderiam identificar as clássicas categorias weberianas da legitimação do poder, no caso, do poder teocrático exercido pelos pais e mães dos terreiros da Bahia: eram eles pessoas que conheciam suas origens étnicas e culturais. Dotados de um superior conhecimento das tradições e reconhecidos por toda a gente como detentores legítimos do saber religioso, dos "fundamentos" como se diz na linguagem dos terreiros; formados nos rigorosos cânones do ritual, dos sacrifícios, do questionamento do destino, das cosmogonias, das teogonias e da ação corretora das normas - Martiniano e Aninha eram ainda dotados de uma aura carismática emanada de suas personalidades poderosas, plenas de sabedoria e de mistério. Viveram queridos, respeitados e temidos. E hoje são lembrados e reverenciados na memória dos terreiros como verdadeiros heróis culturais de sua gente.

Martiniano e Aninha foram as figuras mais importantes e prestigiosas do candomblé da Bahia naquela época. Além de Ramos e Carneiro, muitos outros 
pesquisadores procuravam conhecer e entrevistar o sábio babalaô e a famosa mãe-de-santo. Carneiro serviu de intermediário a vários desses encontros, especialmente com Martiniano. Num artigo introdutório como esse devo, contudo, necessariamente, limitar-me a um levantamento seletivo das muitas fontes escritas que se referem a Martiniano e a Aninha, e a alguns depoimentos pessoais de antigos dignitários dos terreiros - pais e mães-de-santo, ogãs, obas, ebômes que os conheceram em vida. Destes últimos, no caso de Aninha, três são de filhas-de-santo suas: Maria Bibiana do Espírito Santo, Senhora, Mãe do Axé do Opô Afonjá, que era, ainda, bisneta da própria mãe-de-santo de Aninha - Marcelina da Silva, Obá Tossi; Ondina Valéria Pimentel, filha do Balé Xangô José Teodoro Pimentel, Iáquequerê do Opô Afonjá e, com a morte de Senhora, sua sucessora naquele terreiro; e Isolina Ataíde de Araújo, Zozó, Mãe do Candomblé Ilê Babá Omin. Sobre Aninha, ainda, o do Obá Abiodum, Arquelau Manuel de Abreu, parente de Aninha e o de Deoscóredes Maximiliano dos Santos, Didi, filho da ialorixá Senhora; seu livro, Axé Opô Afonjá é uma indispensável referência para a história daquela casa. Quanto a Martiniano, muito importantes foram os depoimentos do Oba Até de São Gonçalo, Miguel Arcanjo Barradas de Santana e do seu filho, o Obá Cancanfô, Antônio Albérico Santana, dentre outros informantes válidos.

Martiniano - "Todo o mundo pensa que eu tenho muito dinheiro mas desde que o Dr. Nina Rodrigues morreu, não tive mais um emprego regular”.

Martiniano Eliseu do Bonfim foi um membro muito influente dos candomblés da Bahia, desde os fins do século XIX. Nina Rodrigues a ele já se referia, sem mencionar-lhe o nome, como um valioso informante:

Há aqui na Bahia diversos negros que aprenderam em Lagos a ler e a escrever a língua iorubá. Não me tendo chegado até agora a gramática e o dicionário iorubano inglês que de Lagos mandei buscar, a tradução e a ortografia das palavras iorubanas empregadas neste trabalho, vão como me foram ensinadas por um moço negro, de pais africanos, que por muitos anos residiu em Lagos.

Esse "moço negro, de pais africanos" era Martiniano. Teria, pelo tempo em que Nina o conheceu, cerca de trinta anos, pois nascera em 1859. Há quem diga que em 1860 ou mesmo 1861, sem muita certeza. Dessa colaboração de Martiniano com Nina, falaria o próprio babalaô, muitos anos mais tarde, em 1938, à antropóloga Ruth Landes: “Todo o mundo pensa que eu tenho muito dinheiro mas desde que o Dr. Nina Rodrigues morreu, não tive mais um emprego regular". Teria sido, pois, Martiniano, um informante remunerado de Nina Rodrigues, sem que se saiba se com algum "vínculo empregatício" como hoje se diz, fosse através da Faculdade de Medicina do Terreiro do Jesus ou a serviço do próprio Nina.

A tradição oral do povo-de-santo e as referências escritas de pesquisadores e escritores como Édison Carneiro, Jorge Amado, Artur Ramos, Áydano do 
Couto Ferraz, Donald Pierson, Ruth Landes, E. Franklin Frazier e outros, transformaram o velho Martiniano numa figura lendária do candomblé da Bahia. Sua vida, seus antepassados, suas viagens à África, seu saber, sua autoridade e participação efetiva - como babalaô e conselheiro - nas mais antigas e prestigiosas casas-de-santo, tudo isto o faz merecedor de um estudo mais aprofundado do que esta breve resenha biográfica. Quando da realização do $2^{\circ}$ Congresso AfroBrasileiro, na Bahia, em 1937, a que Martiniano deu uma colaboração marcante, Jorge Amado escreveu a seu respeito, um comovido "Elogio de um Chefe de Seita", lido pelo autor na sessão de 15 de janeiro daquele congresso. Disse, então, Jorge Amado

[...] Há, porém, sobre todos esses nomes um nome a lembrar, a estudar, a louvar: o do Prof. Martiniano Eliseu do Bonfim, chefe de seita, a mais nobre e impressionante figura da raça negra no Brasil de hoje. Sua sinceridade, seu amor à sua raça, a sua dedicação, a sua inteligência, a sua cultura fazem deste chefe de seita um dos tipos representativos das melhores qualidades dos brasileiros.

E, mais adiante, disse ainda:

Há quase quatro anos um romancista, que queria escrever um romance honesto sobre a raça negra no Brasil, subiu as escadas pobres que conduziam à pobre morada do maior e mais respeitado nome das seitas africanas transportadas ao Brasil e desde então a posição daquele romancista diante deste chefe de seita tem sido a da mais absoluta e comovida admiração.

(Recentemente, Jorge Amado me confirmou, em conversa pessoal, que ele então se referia ao romance Jubiabá, publicado em 1935.) Nina Rodrigues e Jorge Amado tiveram, assim, com o intervalo de mais de quarenta anos, um, no "moço de Lagos" que falava iorubá, o outro, no velho babalaô cheio de sabedoria e de compreensão humana, a palavra de segura informação, de ajuda confiável. E o pioneiro dos estudos antropológicos do negro no Brasil e o grande romancista brasileiro refletiram, dessa maneira, nas suas obras já clássicas, a cultura e o saber de um negro na Bahia.

Em 1936, Édison Carneiro convidou Martiniano para ser o Presidente de Honra do $2^{\circ}$ Congresso Afro-Brasileiro, papel que ele exerceu com grande interesse e dignidade. À véspera da abertura oficial do Congresso, o Estado da Babia, em sua edição de 9 de janeiro de 1937, publicava com destaque: “O $2^{\circ}$ Congresso Afro-Brasileiro/ $\mathrm{Na}$ próxima segunda-feira, 11, às 15 horas, no Instituto Histórico da Bahia / A sessão será presidida pelo Professor Martiniano do Bonfim, antigo colaborador de Nina Rodrigues”. No dia doze, noticiava:

Segundo Congresso Afro-Brasileiro / Como decorreu a sua sessão de instalação / Presidida por Martiniano do Bonfim, o antigo colaborador de Nina Rodrigues, realizou-se ontem, conforme estava marcada, a sessão inaugural do Congresso Afro-Brasileiro da Bahia... Presente grande número de congressistas, o escritor Áydano do Couto Ferraz leu o termo de abertura do 
Congresso, assinado pela Comissão Executiva e logo em seguida passou a presidência ao Professor Martiniano do Bonfim, que se achava ladeado pelo escritor Édison Carneiro e pelo juiz federal Mathias Olympio.

Martiniano teria, ainda, uma participação definitiva na organização da União de Seitas Afro-Brasileiras, criada em decorrência de uma das resoluções do Congresso.

\section{Nascido no Brasil, sob a escravidão,} de progenitores que haviam comprado a sua própria liberdade, foi enviado pelo pai mais ou menos aos catorze anos, a Lagos, na África Ocidental ...

Entre os anos de 1935 e 1940 Martiniano deixaria, em forma de entrevistas dadas, coincidentemente, a três pesquisadores americanos, longos depoimentos sobre a sua vida e a história de sua gente. O primeiro deles foi documentado por Donald Pierson, da Universidade de Chicago, que conheceu e freqüentou Martiniano durante sua estada de 22 meses na Bahia, de 1935 a 1937. Pierson deixou de Martiniano - como de outros líderes do candomblé, como Aninha, Bernardinho do Bate Folhas, Maria Bada e Procópio - uma longa entrevista que fornece valiosos elementos da história de vida de Martiniano e de sua inserção na história social da Bahia dos anos de 1930. Depois, em 1938, esteve na Bahia a antropóloga americana, da Universidade de Columbia, de quem falarei adiante Ruth Landes. Ela descreve em seu livro $A$ cidade das mulheres seus encontros e entrevistas com Martiniano, deixando-nos um retrato vivo, simpático e espirituoso - não isento de alguma malícia - da personalidade fascinante e dominadora de velho babalaô. Sobre o primeiro desses encontros, escreveu:

A primeira pessoa com quem Édison (Carneiro) acertou uma visita formal foi um negro de cerca de 80 anos conhecido como Martiniano - o seu verdadeiro nome era Martiniano Eliseu do Bonfim. Era uma instituição na Bahia e na verdade em todo Brasil; consideravam-no um sábio no seu mundo. Nascido no Brasil, sob a escravidão, de progenitores que haviam comprado a sua própria liberdade, foi enviado pelo pai mais ou menos aos quatorze anos, a Lagos, na África Ocidental, e estudou as tradições tribais de seus antepassados da selva e aprendeu inglês nas escolas missionárias [...]

E mais adiante

[...] Martiniano porém voltou à Bahia, onde sua inteligência perspicaz e sua personalidade dominadora e seus conhecimentos esotéricos foram reconhecidos e o conduziram rapidamente à fama entre os adeptos do candomblé. Os cientistas procuraram-no às vezes para obter informações e o seu nome se notabilizou entre eles, graças ao maior cientista social do Brasil, o Dr. Nina Rodrigues.

Merecem, contudo, esses trechos do livro de Ruth Landes um breve comentário no que se refere à tradução - o "verdadeiro nome" está em lugar de "nome 
completo", enquanto a expressão “antepassados da selva” pode sugerir uma imagem equivocada do tipo de sociedade agrária que vivia em aldeias e pequenas cidades, próprio da organização social e política dos iorubás da Nigéria no século XIX.

Um terceiro americano estaria ainda no caminho de Martiniano. Desta vez o sociólogo da Universidade de Harvard, E. Franklin Frazier, que esteve na Bahia por quase cinco meses, em 1940. De sua pesquisa deixou um artigo "The Negro Family in Bahia, Brazil", publicado em 1942. A entrevista de Frazier com Martiniano revela dados biográficos que são basicamente os mesmos referidos por Pierson e Landes. Algumas pequenas divergências, contudo, não alteram o essencial da informação, coerente nos três relatos: a viagem de Martiniano, adolescente, à Nigéria, sua volta à Bahia, depois de onze anos; sua aprendizagem e formação no culto de Ifá, que o tornaria um babalaô. Nessa entrevista, disse Martiniano a Frazier que

seu pai, que era da tribo egbá, foi trazido para o Brasil cerca de 1820 e liberto em 1842. Sua mãe era da nação iorubá e foi alforriada por seu marido em 1855. Seu pai e sua mãe nunca se casaram de acordo com os ritos católicos nem muçulmanos. Seu avô, que era um guerreiro na África, teve quarenta mulheres e seu pai, seguindo as práticas poligâmicas africanas, teve cinco mulheres, das quais sua mãe era a esposa principal.

E a partir daí, Frazier se estende na análise da estrutura familiar e de parentesco de Martiniano, devido, naturalmente, à orientação específica de sua pesquisa na Bahia - o estudo da família do negro baiano.

Desses depoimentos de Martiniano do Bonfim a profissionais treinados em técnicas de pesquisa social e mais, do corpus da tradição oral do povo-de-santo, muitas são as referências encontradas que merecem ou permitem comentários etno-históricos, sociológicos e lingüísticos. Num trabalho como este, no entanto, não é possível sequer tentar uma análise desse tipo. Ainda assim, devo abordar uns poucos tópicos do valioso material disponível naquelas fontes a respeito de Martiniano do Bonfim, deixando aqui a sugestão para pesquisas mais elaboradas sobre o assunto.

Num trecho, por exemplo, da entrevista de Martiniano a Donald Pierson, ele diz:

O nome de minha mãe era Manjegbassa, que quer dizer "Não deixe eu sozinha”. Ela nasceu depois que a mãe tinha perdido os dois primeiros filhos. Tinha uma cicatriz no rosto para mostrar que era iorubá, porque todos os iorubás, homem e mulher, tem que ter esta marca. Ela casou com meu pai no Brasil e quando eu nasci eles me chamaram de Ojeladê.

Sobre Majegbassa - que se pronuncia Majegbassã é um antropônimo de uma longa série de nomes dados a crianças que nascem e "vingam", isto é, sobrevivem, depois de irmãos natimortos ou mortos na primeira infância. São nomes especiais que procuram "exorcisar" o espírito abiku que ameaça a vida das 
crianças iorubás. Abiku significa, precisamente, "nascido para a morte". Dentre as várias práticas rituais prescritas pelos babalaôs para evitar a reencarnação dos espíritos abiku nos recém-nascidos, seus pais dão às crianças nomes que afastam ou afugentam esses espíritos, assegurando a sobrevivência das mesmas. É muito grande a lista desses nomes, por assim dizer, preventivos, entre os iorubás, todos significando ou expressando o desejo da permanência no mundo, de uma criança nascida abiku. Majebassã é um desses nomes e quer dizer, como explicou Martiniano, "não me deixe sozinha". Martiniano disse, ainda, que sua mãe era ijexá, e tinha as marcas de nação no rosto. E uma fotografia constante do livro de Manuel Querino, Costumes africanos no Brasil, sobreposta à legenda “Tipo Ijexá”, é tida como o retrato de Majebassã, segundo depoimento que teria sido feito por Martiniano a amigos seus. As marcas tribais dos iorubás, de que falou também Martiniano a Ruth Landes, ainda que mal percebidas na fotografia aludida, distinguem os vários grupos étnicos que formavam a antiga nação iorubá.

"Seu pai e sua mãe nunca se casaram de acordo com os ritos católicos nem muçulmanos. Seu avô, que era um guerreiro na África, teve quarenta mulheres e seu pai cinco mulheres, das quais sua mãe era a esposa principal..."

Na sua entrevista a Pierson, disse Martiniano que "seus pais lhe deram, ao nascer, o nome de Ojeladê". Alguns autores contemporâneos sugerem que Ojeladê seja um título, um oiê que Martiniano recebera no culto dos eguns da ilha de Itaparica, onde ele era reverenciado pelos velhos ojés e titulares do culto. Na verdade, contudo, Ojeladê era o nome próprio iorubá de Martiniano. Provém este nome do título sacerdotal de Ojé, do culto dos eguns. Abraham esclarece: “Ojé, título em família que adora os eguns. Donde os seguintes nomes próprios masculinos - Ajelabi, Ojeladê, Ojeniram...". Ojé prefixado - ou aposto - a um complemento nominal, forma uma grande série de nomes próprios e de oiês usados em louvor dos antepassados das linhagens iorubás associadas às complexas categorias da crença na imortalidade e na reencarnação. Martiniano era conhecido e chamado, nos terreiros da Bahia - inclusive no culto dos eguns de Itaparica, por seu nome nagô de Ojeladê. Este nome, por um processo comum de metonímia, passou a ser considerado, na Bahia, como um ioê, um "posto". E depois da morte de Martiniano, em 1943, o nome Ojeladê integrou-se, naturalmente, na hierarquia do culto dos eguns, de maneira que, atualmente, em dois terreiros de Itaparica, existem titulares com o nome de Ojeladê.

Os autores e a tradição oral falam das viagens de Martiniano à África, especialmente da primeira, quando foi levado por seu pai, quando tinha mais ou menos catorze anos. Seu destino foi Lagos, hoje a capital da Nigéria, mas, àquela época, uma colônia que centralizava a crescente expansão colonial inglesa sobre os povos iorubás e seus vizinhos. Martiniano, segundo sua entrevista a Pierson, ficou em Lagos “onze anos e nove meses, de 1875 até 1886”. Mais tarde, retornaria à África - para ele, “África” era Lagos, eram os nagôs/iorubás, sua nação - onde esteve por mais um ano. Três anos depois, tornaria a voltar "para vender coral, lã 
grossa e fina e comprou pano-da-Costa para vender aqui". Só um exame mais pormenorizado dessa entrevista - e das outras nas quais fala de suas viagens, precisaria a exata cronologia da vida de Martiniano, naquele tempo, entre a África e a Bahia. Ainda sobre sua primeira viagem, um antigo Obá do terreiro do Opô Afonjá, que fora muito amigo de Martiniano, contou-me que "o pai dele mandou ele para a África, porque numa briga ele quebrou a cabeça de um rapaz branco, filho de um homem importante e teve que se esconder da polícia”. Outros informantes me confirmaram esta versão com pequenas variantes, inclusive dando a idade de Martiniano como sendo, então, de dezessete anos. Esta idade, no entanto, se choca com a precisa informação de Martiniano a Pierson, de que fora para Lagos com "treze anos e onze meses" (Ruth Landes fala em catorze anos). Prefiro, frente a tais discordâncias, deixar este e outros aparentes anacronismos para serem esclarecidos por uma pesquisa mais documentada, que a vida de Martiniano - e o seu tempo - está a merecer.

\section{[...] Martiniano, que voltou de Lagos "cheio de saber e razão", para integrar-se pelo resto da vida na comunidade baiana que permeava com naturalidade e orgulho.}

Como quer que tenha sido, contudo, a ida à África de africanos libertos e de seus filhos, pelos fins do século XIX, era, naquele tempo, um importante elemento legitimador de prestígio e gerador de conhecimentos e poder econômico. Enquanto negociavam várias mercadorias trazidas da Costa e levadas do Brasil, também, como hoje se diz, reciclavam o saber da tradição religiosa aprendida com "os antigos", nos terreiros da Bahia. Assim foi com Martiniano, que voltou de Lagos "cheio de saber e razão", para integrar-se pelo resto da vida na comunidade baiana que permeava com naturalidade e orgulho. Nas cartas de Carneiro no testemunho dos escritores e pesquisadores, na memória do povode-santo, sua figura e sua lembrança permaneceram vivas.

Martiniano Eliseu do Bonfim e Eugênia Ana dos Santos eram grandes amigos e é sabido que o babalaô colaborou largamente com a ialorixá de São Gonçalo na estruturação do grupo dos Obás ou Ministros de Xangô, como são conhecidos esses oloiês. Aninha concedeu a Martiniano, no Axé do Opô Afonjá, o honroso título de Ajimudá, o que marcou o respeito e a consideração que tinha a venerável mãe-de-santo pelo sábio babalaô. O sentimento, aliás, era mútuo. Depois da morte de Aninha, em janeiro de 1938, Martiniano confessava a Ruth Landes:

[...] Nem mesmo visito os terreiros desde que dona Aninha - descanse em paz! - se foi. Considero-a a'última das mães [...] Sinto saudades dela agora. Acho que toda a Bahia sente. Não faço questão de pisar em nenhum dos outros templos, mesmo que me convidem. Nenhum deles faz as coisas direito como ela fazia. Não acredito que saibam falar com os santos e trazê-los para dançar nos terreiros dos templos. 


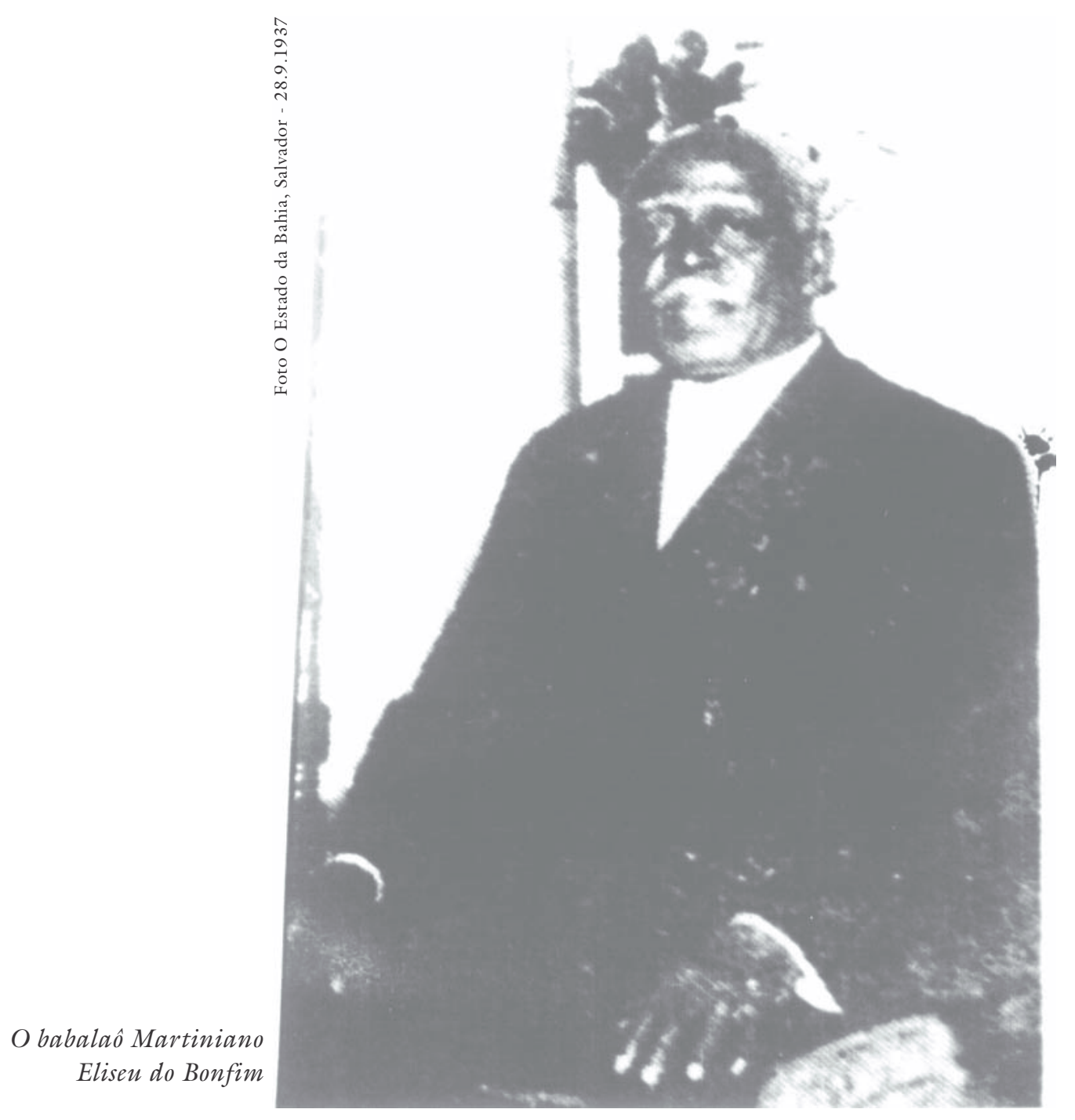

O discurso emocionado de Martiniano - excluindo-se, voluntariamente, das outras comunidades que costumava freqüentar e onde era recebido sempre com as maiores honrarias - privilegiando uma mãe-de-santo morta como a única a merecer sua atenção e respeito, eu ouviria, muito mais tarde, num contexto semelhante, de outra venerável figura dos candomblés baianos, Eduardo Ijexá. O velho pai-de-santo, nos seus oitenta anos já completados, queixou-se longamente, a mim, da ligeireza dos costumes, da improvisação dos rituais e das cantigas, do desconhecimento da língua sagrada do povo-de-santo daqueles dias. E como seu velho amigo Martiniano, o velho pai-de-santo dizia "que nunca mais fora a casa de ninguém, uma ou outra vez ia ainda, ao Engenho Velho, ao Alaqueto, ao Gantois...". Este tom de laudator temporis acti domina a memória dos pais e mães-de-santo da Bahia, que estão sempre evocando "os mitos pretéritos" da tradição de suas casas, de uma forma valorativa e discriminatória. 


\section{Martiniano Eliseu do Bonfim e Eugênia Ana dos Santos eram grandes amigos...}

Também Aninha, falando da origem nagô de seu terreiro, dizia, orgulhosamente, a Donald Pierson:

Minha seita é puramente nagô, como o Engenho Velho. Mas eu tenho ressuscitado grande parte da tradição africana que mesmo o Engenho Velho tinha esquecido. Eles têm uma cerimônia para os doze ministros de Xangô? Não! Mas eu tenho!

A ialorixá Eugênia dos Santos, Aninha, é, pois, a outra figura modelar do candomblé baiano desse tempo. Provinha de uma geração que tipificava o fenômeno da "nacionalização ritual", em que africanos de várias origens étnicas adotavam - ou eram adotados - as comunidades religiosas de terreiros predominantemente “jeje-nagôs” ou "angolas”, ou "congos". Comentando este fato, escrevi, em outro local:

Esses terreiros mantêm, contudo, apesar dos mútuos empréstimos ostensivos e das influências perceptíveis no ritual como na linguagem, os padrões mais característicos e distintivos de suas culturas formadoras [...] Esses padrões dominantes são como a linha mestra num processo multilinear de evolução, aceitando ou rejeitando inovações, adaptando-se à circunstância global; assimilado os empréstimos e adotando as invenções - mas retendo sempre a marca reveladora de sua origem, em meio à integração e à mudança.

Daí a falecida ialorixá Aninha poder afirmar, com orgulho: minha seita é nagô puro. E dizia isto no sentido de que a nação de sua seita, de seu terreiro, e que eram os padrões religiosos em que ela, desde menina, se formara, era nagô, Aí se deve entender nação-de-santo, nação-de-candomblé. Porque, no caso de Aninha, ela mesma era e se sabia etnicamente descendente de africanos grunces, um povo que ainda hoje habita as savanas do norte de Gana e do sul do Alto Volta e que nenhuma relação mantinha com os iorubás até o tráfico negreiro.

Desses grunces já se ocupara Nina Rodrigues que conheceu ainda muitos deles, no fim século XIX. Em Os africanos no Brasil, fala ele dos "guruxins, guruncis ou gruncis, colônia preta, das mais numerosas hoje, e conhecidos pela denominação de negros galinhas". Menciona, ainda, as etimologias populares correntes na Bahia, para o nome "galinha", que expressam racionalizações analógicas e míticas, muito comuns, de resto, na explicação de etnônimos. Acertadamente, Nina prefere a hipótese histórico-geográfica para o termo: os negros galinhas teriam sido embarcados na feitoria existente na foz do rio das Galinhas (o Gallina River dos mapas ingleses), no golfo de Benin. Este porto, muito ativo no tráfico de escravos até meados do século XIX, era o local mais direto ou mais fácil de atingir, para os negros grunces trazidos do norte, contornando a terra perigosa dos axantes. Nina, também corretamente, anota em sua transcrição lata, as formas dialetais com que os grunces pronunciavam o nome de sua nação: grunxi, 
gurunci, grunci... A indicação feita pelos grunces da Bahia a Nina Rodrigues sobre a localização da sua terra, era também correta: acima da terra dos axantes, "de cuja reputação de crueldade ainda falam com terror, ao lado dos Hauçás que vêm traficar e abastecer-se em suas feiras". E conclui: "trata-se, pois, de uma zona africana, de fato, muito pouco conhecida ainda hoje, quase de todos desconhecida até não há muito tempo, para além do país dos Kongs, nos domínios dos Mossis".

Uma análise crítica desse trecho de Nina implicaria uma longa digressão. Hoje sabe-se bem mais sobre os grunces, a região onde habitam, sua cultura, sua língua e falares regionais. Não devo, entretanto, deter-me nesses aspectos da questão.

[...] Aninha, depois dos estágios rituais

e pela sua já reconhecida capacidade de liderança, e ainda com o apoio de velhos tios e tias a quem se ligara, começou sua vida de sacerdotisa, de ialorixá.

Eram, portanto, grunces, os pais de Aninha - Sérgio dos Santos, chamado em grunce Aniió, e Lucinha Maria da Conceição, Azambrió. Eles devem ter participado da intimidade dos grupos mais ou menos hegemônicos que eram os iorubás/nagôs da Bahia daquela época. E Aninha seria cedo iniciada por sacerdotes nagôs da nação que viria a ser a sua, na expressão já referida - "Minha seita é nagô puro". Não se sabe, contudo, a idade em que ela fez o santo em casa de Maria Júlia Figueiredo, na rua dos Capitães, por Marcelina Obatossi. Sabe-se, no entanto, que Marcelina, sua mãe-de-santo, "prima e filha-de-santo de Iá Nassô", uma das fundadoras do terreiro conhecido como Engenho Velho, Casa Branca e ainda, de Ilê Iá Nassô, faleceu em 27 de junho de 1885, quando Aninha, nascida em 13 de junho de 1869, tinha quase dezesseis anos. Utilizo aqui as informações que me foram confiadas pela ialorixá Senhora, Maria Bibiana do Espírito Santo, filha-de-santo de Aninha e bisneta-de-sangue de Marcelina Obatossi: - "Depois da morte de minha vó Marcelina é que minha mãe fez santo no Engenho Velho. Fez Afonjá, com minha tia Teófila, Bamboxê e Joaquim”. Indagada sobre essa segunda feitura no santo, Senhora me respondeu que "isso tinha que ser feito, porque Xangô deu dois nomes na terra de Tapa, Ogodô e Afonjá". Senhora me disse ainda que o ajibonã de sua mãe-de-santo "foi homem, não foi mulher Pedro do Cabeça, marido da finada Tia Tiana, Oloxun, mãe-de-santo de Popó, que morava na rua das Campelas". Não devo aprofundar, aqui, os pequenos desencontros entre essa versão, de uma informante absolutamente confiável - a própria filha-de-santo e sucessora de Aninha, que deve ter ouvido muitas vezes, na tradição oral de rigor, os pormenores relativos à genealogia e à cronologia da vida da sua mãe-de-santo - e outros relatos já documentados em fontes escritas. Não se percebe, aí, a possibilidade do "salto de gerações" ou da "simplificação seletiva”, comuns na evocação das genealogias históricas não documentadas. 
Certos que algumas perguntas ficam, aqui, sem resposta. Mas os claros da cadeia de informações se explicam como "as coisas de que não se deve falar" e são tratadas nos candomblés sempre com reserva e discrição.

Iniciada, muito cedo, Aninha, depois dos estágios rituais e pela sua já reconhecida capacidade de liderança, e ainda com o apoio de velhos tios e tias a quem se ligara, começou sua vida de sacerdotisa, de ialorixá. Com pouco mais de trinta anos já iniciava, com a ajuda de Bamboxê, seu babalaô, sua primeira filha-desanto, no Engenho Velho. Desse período da vida de Aninha, a melhor fonte escrita é, certamente, o livro Axé Opô Afonjá, já referido, de Deoscóredes Maximiliano dos Santos, único filho da falecida ialorixá Senhora, Maria Bibiana do Espírito Santo, portanto, "neto" de Aninha, a quem, de resto chamava, devidamente, de "minha avó". Didi, como é tratado por toda a gente, conheceu Aninha desde menino e cresceu na intimidade do terreiro de São Gonçalo, onde sua mãe, Senhora, ao tempo de Aninha, tinha o posto de Ossi Dagã. O livro foi baseado nas lembranças pessoais do autor e nas informações acumuladas e recorrentes, de sua mãe Senhora e de outras tantas ebomes da casa, irmãs e filha-desanto de Aninha, que lhe transmitiram datas, fatos e histórias dos primeiros tempos de sua "avó". Tudo isto, é claro, com as naturais reservas de episódios e impressões que toda liderança forte e duradoura provoca no plano dos conflitos intragrupais, das restrições pessoais e das "pequenas histórias" que o candomblé, como todo grupo organizado, apresenta na sua dinâmica cotidiana. Um exemplo característico dessa atitude - da discrição, a que me referi acima, e da redução eufemística de fatos que melhor seriam esquecidos, é a maneira como D.M. Santos se refere, no seu livro, à saída de Aninha, do Engenho Velho:

Daí aconteceram certos desentendimentos lá pelo Engenho Velho. Aninha reuniu então todo o seu pessoal e foi para uma roça do Rio Vermelho chamada "Camarão", onde funcionava o terreiro de tio Joaquim Vieira (Oba Sãiyá), filho de Xangô, conhecido também como Essa Oburô, um dos maiores conhecedores das seitas africanas na época, e que era amigo inseparável de tio Bamboxê.

D. M. Santos refere-se, ainda, no capítulo “Os primeiros tempos do Axé”, à movimentada vida religiosa de Aninha, nesse período de formação e afirmação sacerdotal: aos primeiros filhos-de-santo que fez, com a ajuda de velhos tios e tias ligadas ao Engenho Velho, que eram, de certa forma, seus parentes-de-santo, especialmente Bamboxê Obiticô, um dos oficiantes de sua iniciação; bem como às transferências de seu terreiro, do Camarão, no Rio Vermelho, para o alto da Santa Cruz, àquela época, nesse mesmo bairro, hoje, em Amaralina, e à mudança definitiva, em 1910, para a roça do Ano de São Gonçalo do Retiro.

Ali fundou Aninha o seu terreiro, a casa de Xangô Afonjá, com Tio Joaquim, seu amigo e, de certa maneira, irmão-de-santo, que morreria pouco depois em 8 de setembro de 1910, deixando na Casa sua mulher Isidora. Em São Gonçalo, Aninha, uma mãe-de-santo jovem para os padrões da época - aos qua- 
renta e um anos de idade, já era conhecida e respeitada por todos. Em 1911, conta D. M. Santos

[...] Iyá Obá Biyi já estava com 23 pessoas iniciadas por suas mãos (sem contar com as que foram iniciadas em casas particulares e outras dentro do Axé, cujos nomes não chegaram ao conhecido público por motivo ignorado) e vinte homens entre Alabês, Axoguns, Ogans etc. Existia também grande quantidade de pessoas sem posto na casa, que faziam parte e acompanhavam todo o ritual do Axé.

Nota-se, aí, a típica estrutura das comunidades, dos ebés (do iorubá egbé, para comunidade, sociedade, associação) tradicionais da cultura iorubá nagô. Essa forma associativa permanece, reconhecível ainda hoje, nos terreiros da Bahia, apesar das mudanças porque vem passando a sociedade de classes em que o candomblé, como um sistema simbólico interativo, se insere. Esse padrão tradicional dos ebés envolve, naturalmente, uma liderança, um chefe e uma numerosa hierarquia, além de aderentes e associados informais, com vagos compromissos rituais. Os titulares, donos de postos ou cargos, se encarregavam das diferentes atividades rituais do ebé. Todos, iniciados, sabedores das coisas, e cada um com seu saber específico, ajudando a liderança para além do conhecimento iniciático geral, que era de toda a coletividade. Assim, Aninha foi iniciada por Marcelina e Bamboxê, mas também com Tia Teófila e Tio Joaquim. Assim, também ela, por sua vez, fez suas primeiras filhas-de-santo, ajudada - o que não significa, simplesmente, acolitada, mas partilhando o ritual iniciático com Bamboxê, com Tio Joaquim, com o Balé Xangô, José Teodoro Pimentel, que substituiu, nesse cargo, Bamboxê Obiticô por morte deste último. Mais tarde, com sua irmã-desanto Fortunata, iniciaria outras filhas-de-santo, na ilha de Itaparica, em casa do Balé Xangô, cuja filha, Ondina Valéria Pimentel, uma das iniciadas desse grupo, viria a ser, ainda muito jovem, a iá-quequerê de São Gonçalo e, como já foi dito, por morte da ialorixá Senhora, de quem era irmã-de-santo, assumiria a chefia daquele terreiro. Com o tempo - e já nos anos de 1930, esse tipo de co-participação diminuiria nos terreiros da Bahia. Pelo menos, de tal maneira ostensiva, regulada pelo saber iniciático dos velhos tios - todos iguais no plano do conhecimento, mas cada um especializado, por assim dizer, em determinados orôs ou tendo compromissos rituais com certos orixás - o que os tornava indicados para a co-paternidade ritual. Mas ainda assim, a iniciação tinha um líder, um chefe; "o que botava primeiro a mão na cabeça da iaô". E essa metáfora temporal definia a autoridade principal nas complexas cerimônias iniciáticas. E ajudando a mãe, estavam os tios e as tias, na participação conjunta que era, também, troca de conhecimentos de iniciação e enforçamento da solidariedade comunitária.

Édison Carneiro escreveu, dias após a morte da ialorixá Aninha, em 3 de janeiro de 1938, um emocionado artigo sob o título "Dona Aninha", publicado no Estado da Babia de 25 de janeiro. O artigo foi republicado em Ladinos e crioulos, em 1964, na seção do livro “A face dos amigos”, como“"Aninha”. E o 
fato de ser o primeiro da série evidencia, com o destaque editorial, a importância que lhe dava Carneiro e a admiração que tinha pela ialorixá a quem, respeitosamente, chamava de "Dona Aninha".

Carneiro, então, a descreve:

Essa negra alta, disposta, falando claro e corretamente, o beiço inferior avançando em ponta, era bem o expoente da raça negra do Brasil, síntese feliz da soma de conhecimentos da velha Maria Bada e da agilidade intelectual de Martiniano do Bonfim.

E sobre a sua condição de superior guardiã e renovadora coerente das tradições ancestrais, afirma, no mesmo artigo:

Muito fez pela preservação das tradições africanas no candomblé da Bahia. Darei apenas dois exemplos. Em quarto guardado à vista dos curiosos e de estranhos, prestava culto a Yá, a deusa das águas dos negros galinhas (grunces), uma tradição já, então, desaparecida. E foi Aninha quem, no ano passado (1937), trouxe para o Opô Afonjá a festa africana dos obás de Xangô, empossando os seus doze ministros com o rito próprio, há muito esquecido pelos chefes e pelos aderentes das religiões populares.

O culto da "deusa das águas dos negros galinhas", a que se refere Carneiro, é também mencionado por D. M. Santos, ao falar sobre a implantação do terreiro de São Gonçalo por Aninha

[...] Daí, Iyá Obá Biyi, com sua boa vontade, seu espírito batalhador e a ajuda de todos que acompanhavam, continuou a construir o Axé, fazendo casas nos assentos já existentes para Exu, para Oxalá, está com um quarto para as Ayabás, para a Iemanjá denominado Ilê Iyá, onde Mãe Aninha adorava Iya n'ilé Gruncis (a mãe da terra de Gruncis, na África), outra para Obaluaiê, a de Oxossi e a casa de Ilê Ibô Iku (casa de veneração aos mortos) [...]

Nesse quarto, uma extensão da casa de Oxalá, mas dela independente pela fachada voltada para a casa de Xangô, não se acende luz elétrica e até hoje se mantém, no ciclo das festas da Casa, uma obrigação especial para a santa da terra dos pais de Aninha. Esta misteriosa e preservada santa, a Iyá dos grunces - remanescente de um panteão para sempre perdido, é assim identificada com a Iemanjá nagô, também uma santa das águas, dos rios. Pode-se, até supor que talvez fossem semelhantes em suas epifanias originais. Ambas divindades das águas, dos rios. A Ia dos grunces, quem sabe de que afluente do rio Volta e a Iemanjá nagô, do rio Ogun que corta a terra dos egbás. Foi, aliás, na casa de Iá, que Aninha como conta D. M. Santos - quis morrer, num retorno definitivo à terra africana de seus pais, Aniió e Azambriió:

[...] Pediu que a levassem para a casa de Iyá, onde, depois de ter feito alguns preceitos com o cuidado e o auxílio da maior parte das suas filhas-de-santo, que lá se encontravam, alguns Obás e Ogans também presentes, perdeu a fala e veio a falecer, às quinze horas, na presença de seu médico assistente, dr. Rafael Menezes que ainda chegou a tempo de vê-la dar o último suspiro. 
Carneiro também se refere à implantação do grupo dos Obás ou Ministros de Xangô, em cerimônia por ele assistida, e, ainda, à participação de Aninha no $2^{\circ}$ Congresso Afro-Brasileiro. Carneiro conta que só às vésperas do Congresso pôde avistar-se com Aninha e como foi este encontro com a ialorixá:

No dia seguinte, domingo, fomos, pessoalmente, vê-la. A recepção excedeu a expectativa, pois em vez de uma simples mãe-de-santo que se mostrava favorável ao Congresso, encontramos umas mulher inteligente que acompanhava e compreendia os nossos propósitos, que lia os nossos estudos e amava a nossa obra. Aninha se comprometeu a escrever um trabalho sobre os quitutes trazidos pelo negro para a Bahia. E em apenas três dias de prazo, o Opô Afonjá pôde oferecer aos congressistas uma das mais belas noites que há memória nos fastos do candomblé da Bahia.

E continua Carneiro:

Posso dizer o mesmo do seu apoio à União das Seitas Afro-Brasileiras, fundada a 3 de agosto de 1937, com o fim especial de defender a liberdade religiosa sempre periclitante dos candomblé da Bahia.

Quanto à festa do Opô Afonjá, por ocasião do 2 o Congresso Afro-Brasileiro, foi assim noticiada no Estado da Bahia de 14 de janeiro:

Tiveram grande brilhantismo as festas de ontem do $2^{\circ}$ Congresso Afro-Brasileiro. À noite os congressistas em marinetti especial, foram visitar o Centro Cruz Santa do Axé do Opô Afonjá, de D. Aninha, em São Gonçalo do Retiro. Ali os esperava uma festa especialmente preparada para os congressistas. Todo o terreiro estava aberto à visita dos congressistas. A festa do Opô Afonjá encantou sobremaneira os congressistas.

É bom que se evoquem esses fatos, cinqüenta anos depois de ocorridos quando uma mãe-de-santo tradicionalista e rigorosa não hesitou em organizar uma festa em seu terreiro, fora do calendário ritual, para uma finalidade que ela considerou (e o Xangô da casa decerto confirmou!) necessária a um propósito válido. Não houve, então, contudo, qualquer concessão indevida, nenhuma quebra de norma - mas o pleno exercício da autoridade e da capacidade de decidir, dentro da coerência dos princípios, do "ritmo da casa", como costuma dizer a ialorixá Senhora. Aninha cumpriu o prometido a Carneiro e preparou um pequeno trabalho sobre a culinária africana, entregue aos organizadores do Congresso, depois do seu final, e por eles incluídos como Apêndice ao volume $O$ negro no Brasil, (Rio de Janeiro, Civilização Brasileira, 1940), com o título "Nota sobre comestíveis africanos". A "Nota” é uma breve lista de vinte cinco qualidades de comidas, todas com nomes iorubás (menos uma - "farofa") e descritas as que o foram, com extrema simplicidade, com breves referências à forma ou ao ingrediente básico nelas utilizados. Nenhuma informação, no entanto, sobre a "maneira de fazer" e, menos ainda, ao seu possível emprego ritual no candomblé. Esse despojamento nas "receitas" de Aninha indica, claramente, no campo da comida ritual, o que significa, para o povo-de-santo, a reserva nas "coisas-de- 
fundamento". Pois as "comidas africanas" listadas por Aninha eram, todas elas, comidas-de-santo, oferecidas nas obrigações aos orixás, que têm suas próprias preferências alimentares, sempre associadas a seus mitos e a uma complexa prescrição simbólica. Aninha ficou, assim, para atender ao pedido de Carneiro, no extremo limite que podia se permitir: uma lista quase sinótica de comidas africanas, sem de nenhuma maneira relacioná-las com os sacrifícios e as oferendas votivas aos orixás. Atendeu ao pedido do amigo, mas o fez com as reservas do seu código de mãe-de-santo.

Aninha - do mesmo modo que Martiniano - era acessível ao questionamento, à curiosidade científica ou jornalística dos profissionais que a procuravam. Não se negava a informar, a comentar, a discutir. Guardava, naturalmente, e também aí como seu “irmão" Martiniano, o rigoroso preceito do segredo ritual, da doutrina e dos mitos essenciais de sua religião, como também o sentido exato das "conveniências sociais" - cortesia e reserva. Sua filha-de-santo, a ialorixá Senhora, costumava evocar, em momentos de ocasional confidência, a figura de sua mãe-de-santo, sábia, altiva, rigorosa e autoritária mas, igualmente, generosa, tolerante, compreensiva. Aninha, segundo ela, “ensinava e vigiava”. E assim promovia, indicava e preteria, na medida da inteligência, do esforço e do aproveitamento, suas filhas-de-santo, na hierarquia de mando do terreiro.

Donald Pierson também descreveu Aninha:

A mãe-de-santo chama-se Aninha. Ela é uma preta alta e majestosa, cujo menor gesto é imediatamente obedecido pelos membros de sua seita [...] Ela se gaba, com orgulho, sou filha de dois africanos, graças a Deus [...] Inteligente, viva de espírito, ágil no debate, ela é um dos mais grandemente respeitados e obedecidos líderes do mundo afro-brasileiro.

E a seguir relata uma discussão de Aninha com um sacerdote católico:

Quando um padre, discutindo com ela, lhe disse que ela, não sendo ordenada pelo Papa, não tinha "autoridade espiritual" para executar ritos religiosos, ela perguntou logo se Moisés, "aquele grande profeta e chefe de seu povo" tinha sido ordenado pelo Papa? O primeiro homem, ela afirmava, não deve ter sido um homem branco, mas sim um homem de cor, "se não preto, pelo menos vermelho". Pois os sábios não dizem que o homem se originou na Ásia, e os brancos vieram daquele continente? Jesus deve ter sido um africano ou pelo menos uma pessoa bem escura. Seus pais não o esconderam no Egito? E o Egito não está na África? Se Jesus não fosse escuro, como eles poderiam tê-lo escondido entre o povo da África?

Pierson cita, ainda, argumentos de Aninha no seu discurso teológico:

Somos tão cristãos como os católicos. Mas seguimos também a lei de Moisés. Ele ordenou que os sacrifícios fossem feitos com carneiros, cabras, bois, galinhas, pombos e assim por diante. Não é verdade? Nós apenas obedecemos a seus mandamentos. Existem duas partes na Bíblia, não é assim? Velho e o Novo Testamento. Nós seguimos o Velho tanto quanto o Novo. Antes de Cristo, o povo adorava deus com cantos e danças. Não é verdade? Davi tocava harpa, 
cantava salmos e dançava ante o Senhor. Nós temos nossos cantos também e cada um deles tem uma significação especial. Assim como os católicos têm imagens para seus santos, nós temos alguma coisa para lembrar os nossos orixás. Mas não adoramos imagens feitas pelas mãos dos homens como eles fazem. Adoramos a natureza.

E Pierson comenta, neste ponto:

Basta, talvez, estas citações para dar uma visão do "mundo mental” desta personagem de projeção nos círculos afro-brasileiros. Uma de suas assistentes, uma preta velha que tomava conta do terreiro e que diziam ter mais de noventa anos, tinha um nome africano e falava nagô tão bem ou melhor que o português.

Aninha afirmava-se, a cada dia, como uma mãe-de-santo competente, empreendedora e prestigiosa. Sua reputação a fazia procurada por pessoas que se situavam, socialmente, fora dos estratos de classe dominantes nos terreiros de candomblé. No começo da década de 1930, Aninha viajou para o Rio de Janeiro. Sobre esta e outras viagens ao Rio - de navio, carregada de bagagens, levando o axé de seu santo, acompanhada, sempre, de uma pequena corte de filha-de-santo, correm muitas histórias. Cheguei a ver, há muitos anos, mostrada por Senhora, uma lista feita por Aninha dos "preparos" para uma “obrigação" que ela fizera no Rio, em favor do restabelecimento do então Presidente Vargas, acidentado, como a família, na estrada de Petrópolis (onde andará, hoje, esse papel, nos "guardados" do terreiro?). Sabia-se de suas relações íntimas com pessoas associadas ao Governo da República, diplomatas, Ministros, Chefes de Polícia. Dessas viagens ao Rio resultou a criação, ali, de um ramo do Opô Afonjá, cuja direção entregou à sua filha-de-santo Agripina Sousa.

\section{Corpo de Aninha foi transferido, à noite, para a Igreja de Nossa Senhora do Rosário, no Pelourinho, de onde sairia o cortejo fúnebre, no dia seguinte...}

Voltou Aninha, do Rio, em 1935. Na sua ausência, chefiaram o terreiro sua irmã-de-santo Fortunata, a dagã do terreiro, Silvana, sua filha, a iámorô e senhora, de Oxum, a ossidagã. Dirigiam elas as obrigações anuais; cuidavam dos filhos da casa; atendiam ao serviço diário dos santos, pois que certas obrigações, como a iniciação ou feitura do santo só poderiam ser feitas com a participação pessoal da mãe do terreiro. E de novo em sua casa, em São Gonçalo, Aninha retomou a plena direção do Axé, começando a construção do novo barracão, e de casas para outros santos da casa, e organizando a Sociedade Cruz Santa do Axé do Opô Afonjá que teve, como Presidente de honra, precisamente, o babalaô Martiniano Eliseu do Bonfim, o Ajimudá do terreiro.

Aninha adoeceu - ou começou a mostrar-se doente, o que não é bem a mesma coisa - no começo de 1937. Ainda assim, continuou com seu trabalho na roça, recolhendo as iaôs que estavam preparadas para fazer o santo, e seu último 
barco, com suas últimas filhas-de-santo, saiu em 13 de dezembro de 1937. Uma semana depois da festa do nome das suas últimas iaôs, Aninha piorou e teve de acamar-se. Também aqui será melhor citar, na íntegra, um autor que foi parte do acontecimento - Deoscóredes M. dos Santos, Didi, o Assobá da casa, então com vinte e um anos de idade:

No dia 3 de janeiro de 1938, às nove horas, Iyá Obá Biyi reconheceu a hora da morte, uma vez que, devido aos seus conhecimentos, estava ciente do seu fim e tinha até roupas preparadas para o enterro. Chamou, então, seu neto, o Assobá (eu próprio), o Obá Aré, Miguel A de Santana e a Ossi Dagan, Senhora. Chegaram imediatamente e se apresentaram ao lado da cama onde ela se encontrava, em um quarto da atual casa de Ossanhe. Iyá Obá Biyi (Mãe Aninha), já com a fala um pouco incompreensível, disse: "Obá Aré, Obá Abiodun fica como Presidente da Sociedade, e você eu quero que fique ao lado de Ossi Dagan, Iessé orixá (nos pés do Santo)”.

Logo em seguida, ela virou língua e falou em iorubá, dizendo algumas coisas que nenhum deles entendeu. Então ela disse: "Não sabem o que perderam". Foi então que ela pediu para ser levada para a casa de Iá, onde faleceu às três horas da tarde. Quanto às últimas palavras ditas por Aninha, na língua sagrada de sua nação-de-santo - e que as pessoas que a assistiam não puderam entender foram a derradeira afirmação de seu poder, de sua autoridade no terreiro que criara e onde reinara de modo absoluto.

O corpo de Aninha foi transferido, à noite, para a Igreja de Nossa Senhora do Rosário, no Pelourinho, de onde sairia o cortejo fúnebre, no dia seguinte, 4 de janeiro, no começo da tarde, em direção ao Cemitério das Quintas dos Lázaros. Édison Carneiro e D. M. Santos (Didi) deixaram precisas descrições do sepultamento de Aninha. E o Estado da Babia de 5 de janeiro publicou sobre o mesmo uma ampla matéria, em cinco colunas e com três fotografias. Segundo a mesma, mais de duas mil pessoas compareceram e acompanharam, a pé, o cortejo, até as Quintas; o comércio das imediações da Igreja do Rosário, no Taboão e na Baixa dos Sapateiros, cerrou suas portas em homenagem a Aninha, muito querida e respeitada na área e dela moradora, por longos anos, em casa vizinha à Igreja onde foi velado o seu corpo. Diz, ainda a reportagem, que "o Cônego Assis Curvelo, na capela do cemitério, fez a encomendação do corpo, seguindo-se o sepultamento em cova recém-aberta". Falaram, na ocasião, vários oradores, entre estes o Sr. Álvaro MacDowell de Oliveira, em nome da União das Seitas AfroBrasileiras da Bahia, o escritor Édison Carneiro, além de representantes do Centro Cruz Santa e da Irmandade do Rosário. Por fim, terminada a cerimônia, duas marinettis levaram grande número de amigos de Aninha para São Gonçalo, a fim de tomar parte nas cerimônias fúnebres preparatórias do axexê da querida mãede-santo". Devendo-se assinalar, aqui, o fato de entre os oradores, por ocasião do seu sepultamento, haver também estado o velho amigo e irmão Martiniano do Bonfim. 


\section{As figuras de Martiniano e Aninha sobressaem, assim documentadas fartamente $[\ldots]$ até certo ponto mitificadas pela lembrança coletiva das comunidades dos candomblés.}

Por sua vez, D. M. Santos, no capítulo "Morte e sucessão de Aninha”, do seu livro Axé Opô Afonjá, depois de contar, com pormenores, todas as cadências do enterro da ialorixá, incluindo mesmo certas obrigações rituais do candomblé, conclui:

Assim foi sepultada Iyá Obá Biyi, Eugênia Ana dos Santos, conhecida por Mãe Aninha, com as formalidades de praxe dentro da religião católica e do culto afro-brasileiro. Repousa, atualmente, num belo mausoléu oferecido pela Sociedade Beneficente Cruz Santa Opô Afonjá.

Define este último trecho as relações de Aninha com a Igreja Católica, de cujos ritos e sacramentos ela participava com devoção: uma coexistência doutrinária e ritualística, sem maiores conflitos em sínteses de caráter teológico, que era esta, afinal, a atitude dominante nas antigas mães-de-santo da Bahia, que sabiam conciliar as duas tradições religiosas para além das contradições dos dois sistemas. Aninha, a poderosa Mãe de Terreiro do Opô Afonjá era, também, Priora das Irmandades do Senhor Bom Jesus dos Martírios e de Nossa Senhora do Rosário e Provedora Perpétua de Nossa Senhora da Boa Morte, da Barroquinha. Era, ainda, Irmã Remida da Irmandade de São Benedito, nas Quintas.

Essas as figuras que, não ao acaso, escolhi, para exemplificar o fenômeno da liderança nas comunidades dos terreiros da Bahia nos anos de 1930. O babalaô Martiniano e a ialorixá Aninha, sendo singulares, não foram, entretanto, únicos, naquele universo povoado de personalidades criativas e dominadoras. Lá estavam, nesse tempo, Tia Massi, do Engenho Velho; Menininha, do Gantois; Dionísia, do Alaqueto; Bernardino, do Bate-Folhas; Procópio, do Ogunjá; Ciriáco, já na Vila América; Cotinha, do Oxumarê... e tantos mais. Todos vivendo no mundo das esperanças e das crises. Nem foram, com certeza, Martiniano e Aninha, imunes à crítica, à censura velada ou ostensiva nem aos sutis mecanismos do “fuxico", instituição universal que, se provoca tensões, igualmente as resolve, pelas estratégias codificadas da linguagem. Omiti, deliberadamente, esses aspectos que não posso chamar de "negativos", da história lembrada - ou recriada? dessas figuras já lendárias. Fui seletivo no uso das fontes escritas e orais, sem a preocupação de ter, no apoio talvez excessivo das remissões e notas, a "legitimação" de um ensaio interpretativo de um curto período da história social da cidade da Bahia. Lembrando, no entanto, que as fontes escritas para uma história do Candomblé são, afinal, as fontes orais da narrativa. Pois o que disseram os pesquisadores - de Carneiro a Verger -, foi recolhido na tradição oral das casasde-santo: seus mitos, suas, por vezes, contraditórias genealogias, suas racionalizações sobre o tempo e o espaço. Como por exemplo, o livro que citei, muitas vezes, de Deoscóredes M. Santos, Didi, fundamental sob tantos aspectos, para o 
conhecimento da organização e da história de "uma casa de Queto", da "nação de Queto" - que é o terreiro fundado por sua "avó”Aninha, por tantos anos dirigido por sua mãe Senhora, é, também, e sobretudo a tradição oral da casa, cuidadosamente escrita, evitando referências a fatos polêmicos relacionados com genealogias imprecisas ou sucessões discutíveis.

As figuras de Martiniano e Aninha sobressaem, assim documentadas fartamente em pontos secundários mas muito importantes, nítidas todavia, até certo ponto mitificadas pela lembrança coletiva das comunidades dos candomblés. De um ponto de vista historiográfico (e falo como um antropólogo que não renega a História), dentro da abordagem valorativa do cotidiano e das mentalidades, os documentos que formam a correspondência ativa de Édison Carneiro a Artur Ramos ficam, a partir de agora, à disposição dos estudiosos e dos especialistas. Neste ensaio ou nesta tentativa de interpretação, fui, como disse antes, seletivo e crítico. Optei, às vezes, pela versão de um certo fato com base na confiabilidade de um determinado informante ou em raros documentos oficiais - como o testamento de Marcela da Silva, a antiga mãe-de-santo do Engenho Velho, que, devidamente analisado, poderá ajudar a esclarecer a debatida cronologia das casas “de Queto" da Bahia, originadas do Engenho Velho, da casa de Iá Nassô.

Tentei, dessa maneira, contribuir, no campo da etnohistória, para a ampliação do conhecimento acerca da participação do negro na sociedade nacional, expondo um quadro narrativo do candomblé na Bahia dos anos trinta, ressaltando as personalidades de seus líderes e a lembrança encapsulada latente nos terreiros e neles atuando em meio ás formas novas de conhecimento e de poder.

Nota

* Texto não integral de artigo inserido no livro intitulado Cartas de Édson Carneiro a Arthur Ramos, em que figuram como autores Waldir Freitas Oliveira e Vivaldo da Costa Lima, publicado pela Editora Corrupio, em 1987. Autorizados pelo autor, foram feitos os seguintes cortes: a apresentação inicial, aproximadamente seis páginas, e 56 notas explicativas Os intertítulos foram colocados pela editoria de Estudos Avançados. (Marco Antônio Coelho)

RESUMO - O TEXTO resgata a atuação de duas personalidades eminentes do candomblé da Bahia, na década de 1930: o babalaô Martiniano Eliseu do Bonfim e a ialorixá Eugênia Ana dos Santos, a famosa Aninha, do Centro Cruz Santa do Axé do Apo Afonjá.

Martiniano, nascido na Bahia, era filho de escravos alforriados, tendo sido enviado por seu pai para estudar a língua ioruba e as tradições africanas em Lagos, na Nigéria. Voltando a Salvador, tornou-se um líder religioso e sempre manteve estreita ligação com destacados intelectuais baianos. Aninha foi outra figura modelar entre as comunidades religiosas de terreiros, destacando-se pela sua indiscutível capacidade de liderança. Tan- 
to Martiniano como Aninha contribuíram para o grande êxito do Segundo Congresso Afro-Brasileiro, realizado em Salvador, em janeiro de 1937.

ABSTRACT - THIS ESSAY recalls the life and work of two eminent personalities of the Candomble religion in Bahia in the 1830s: babala $\hat{~[Y o r u b a ~ p r i e s t] ~ M a r t i n i a n o ~ E l i s e u ~}$ do Bonfim and ialorixá Eugênia Ana dos Santos, the renowned Aninha, spiritual director and priestess of the Cruz Santa do Axé do Apo Afonjá Center.

Martiniano, born in Bahia, was the son of emancipated slaves. He was sent by his father to study the Yoruba language and African traditions in Lagos, Nigeria, and upon returning to Salvador, became a religious leader, maintaining close relationships with noted intellectuals from Bahia. Aninha was another model figure among the religious communities of the terreiros [ritual grounds of the Candomble religion], who stood out for her incontrovertible leadership ability. Both Martiniano and Aninha contributed to the huge success of the Second Afro-Brazilian Congress held in Salvador in January 1937.

Vivaldo da Costa Lima é antropólogo e professor emérito da Universidade Federal da Bahia (UFBA).

Texto recebido e aceito para publicação em 29 de setembro de 2004. 